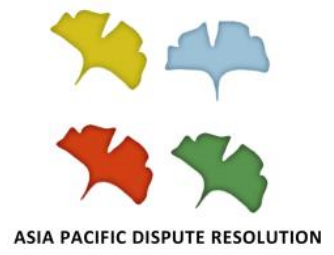

\title{
The Role of Chinese Financial Institutions in Promoting Sustainable Investment under the One Belt One Road Initiative
}

\author{
Bingyu Liu \\ Peter A. Allard School of Law \\ University of British Columbia
}

APDR Working Paper Series

Volume 1 Number 1

ISSN 2371-6304

(c) (i) ()

This article is made available as part of the Asia Pacific Dispute Resolution Working Paper Series and is licensed under a Creative Commons AttributionNonCommercial-NoDerivatives 4.0 International License

$$
\text { (CC-BY-NC-ND) }
$$




\title{
THE ROLE OF CHINESE FINANCIAL INSTITUTIONS IN PROMOTING SUSTAINABLE INVESTMENT UNDER THE ONE BELT ONE ROAD INITIATIVE
}

\author{
Bingyu Liu ${ }^{1}$ \\ Peter A. Allard School of Law \\ University of British Columbia
}

\section{Introduction}

Chinese financial institutions are playing an increasingly important role in Chinese companies' investment overseas in the context of China's One Belt One Road Initiative (OBOR). While the financial support is flowing under OBOR, one concern is the management of environmental and social risks by Chinese financial institutions, particularly in countries with weak environmental governance. Questions have been raised on whether Chinese financial institutions are properly incorporating social and environmental risk into their investment overseas, and on the extent to which the project cycle is governed by financial institutions in a transparent and accountable manner. The integration of environmental, social considerations into its business operations and lending practices, is pivotal to embrace the sustainable development of Chinese foreign investment in the long-term. Few scholars have generally examined Chinese financial institutions' social and environmental governance of their overseas financed projects during OBOR construction. This paper fills this gap by analyzing the role of financial institutions in promoting sustainable investment. Beyond scholarly contributions, this paper has practical policy implications. It provides a better understanding on how to promote the development of Chinese financial institutions' environmental and social protection frameworks and the inclusion of environmental and social considerations into their lending and investment policies. The paper first outlines the relationship between environmental and social risks with Chinese financial institutions and advocates the necessity to develop green finance in ensuring that China's overseas investment is made in a manner that is green, inclusive, and accountable. The paper further introduces Chinese and Chinese-led financial institutions participating in OBOR and China's policy development of sustainable lending and investment. Through comparing the environmental and social protection

\footnotetext{
${ }^{1} \mathrm{PhD}$ Candidate in Law at the Peter Allard School of Law, University of British Columbia, Canada. Email: gloria.bingyu.liu@alumni.ubc.ca
} 
framework between Chinese financial institutions and multilateral financial institutions, the paper proposes policy and management suggestions to promote China's sustainable financial investment in the future.

\section{Environmental and Social Risks of China's One Belt and One Road Initiative}

In 2013, Chinese President Xi Jinping announced China's intention to develop The Silk Road Economic Belt and the 21st Century Maritime Silk Road. Also known as the One Belt and One Road Initiative (OBOR), China's efforts are expected to enhance inter-regional connectivity by focusing on five areas: policy coordination, facilities connectivity, unimpeded trade, financial integration and people-to-people bonds. ${ }^{2}$ The routes will encompass over 60 countries, accounting for $60 \%$ of the world's population and a collective GDP equivalent to $33 \%$ of the world's wealth. ${ }^{3}$ China has rapidly become one of the world's biggest overseas investors and has increasingly encouraged more companies to go abroad. As of the end of 2017, China's non-financial outward direct investment amounted to US $\$ 120$ billion in 6236 overseas companies in 174 countries and regions. ${ }^{4}$ However, there are many risks and challenges during the implementation of OBOR. The different economic and political situations of the countries along the OBOR routes inevitably generate inherent uncertainties and risks. OBOR-related projects encounter political, regulatory, and social and environmental challenges, such as the project's lack of social acceptance, inadequate regard for labour and working conditions, lack of consideration of indigenous peoples' land property rights, and environmental degradation. Improper handling may result in conflicts with local communities or direct economic losses that affect Chinese overseas companies' longterm interests.

\footnotetext{
${ }^{2} 2017$ Report on the Sustainable Development of Chinese Overseas companies Overseas Supporting-The Belt and Road Regions to Achieve the 2030 Agenda for Sustainable Development, online:< http://www.cn.undp.org/content/dam/china/docs/Publications/2017\%20Report\%20on\%20the\%20Sustainable\%20De velopment\%20of\%20Chinese\%20Enterprises\%20Overseas.pdf?download> accessed May 25, 2017

${ }^{3}$ Ibid.

${ }^{44}$ Database of Commerce of the People's Republic of China, online: <http://www.mofcom.gov.cn/article/tongjiziliao>, accessed January, 2018. For more information on One Belt One Road, see National Development and Reform Commission, "Vision and Actions on Jointly Building Silk Road Economic Belt and 21st-Century Maritime Silk Road" (2015), online: <http://en.ndrc.gov.cn/newsrelease/201503/t20150330_669367.html>, accessed September 7, 2016.
} 
Among all the risks, environmental risk is an important one which includes physical environmental risk and transitional environmental risks. ${ }^{5}$ Physical environmental risks include environmental degradation, lack of sustainability or efficiency in natural resource management, and inadequate pollution prevention throughout planning, development, construction, operation, and termination phases of an investment project. ${ }^{6}$ Some areas along the OBOR possess abundant natural resources, but also have fragile and sensitive ecological environments that can be prone to severe natural disasters such as sand-storms, droughts, water and soil erosion at same time. ${ }^{7}$ Furthermore, as Chinese companies are regarded as some of the most significant producers of global carbon emissions, the carbon emissions levels of Chinese companies overseas have also drawn much attention from the international community. ${ }^{8}$ To address domestic industrial overcapacity and meet the demand for the construction of infrastructure and electricity facilities of countries along the OBOR, Chinese investment in fossil fuel investment and infrastructure building accounts for a significant portion of OBOR investments. As China's investment is mainly concentrated in the highly carbon-intensive industries, the carbon emissions levels of Chinese companies overseas have also drawn much attention from the international community. ${ }^{9}$ To respond to the Intended Nationally Determined Contributions under the United Nations Framework Convention on Climate Change, many countries along OBOR have required foreign investors to reduce the carbon emission of the industries and introduce policies to support clean energy. Changes to regulations and policies on renewable energy therefore have posed a threat to the survival of Chinese coal, oil, and thermal power companies overseas, ${ }^{10}$ and lead to losses for the financial institutions that provided loans to these affected companies.

\footnotetext{
${ }^{5}$ Jun Ma, Establishing China's Green Financial System, China Financial Publication House. See also, Environmental Risk Management Initiative for China's Overseas Investment <http://www.greenfinance.org.cn/displaynews.php?id=1472>, accessed May 10, 2017.

${ }^{6}$ Daojiong Zha, ed., Chinese Investment Overseas: Case Studies on Environmental and Social Risks (Peking University Press).

${ }^{7}$ EY Knowledge (Global Markets), "Riding the Silk Road: China Sees Outbound Investment Boom: Outlook for China's Outward Foreign Direct Investment" (2015).

${ }^{8}$ At present, more than $40 \%$ of China's coal-fired projects are planned (and signed) and under construction, such as the construction of a new pipeline across Myanmar and the construction of a number of coal-fired power plants in Indonesia, Pakistan, Turkey, and African and Latin American counties. From 2001 to 2016, the Chinese government invested in more than 50 coal-fired power plant projects overseas.

${ }^{9}$ Zha, supra note 6; EY Knowledge (Global Markets), supra note 7.

10 "Report on the Sustainable Development of Chinese Enterprises Overseas: Supporting The Belt and Road Regions to Achieve the 2030 Agenda for Sustainable Development" (2017), online: $<$ http://www.cn.undp.org/content/dam/china/docs/Publications/2017\%20Report\%20on\%20the\%20Sustainable\%20
} 


\section{The Necessity of Green Finance to Address Environmental and Social Risks of OBOR}

In the context of Chinese investment overseas, Chinese companies' environmental and social performance in host countries is influenced by different economic, political, environmental, and social stakeholders. ${ }^{11}$ Among all the stakeholders, financial institutions constitute a significant group of actors that could play an important role in minimizing the environmental and social risks of the financed projects. China has put together a list of major deliverables during the OBOR Forum, which includes China's plan to increase its financial contribution to the OBOR. ${ }^{12}$ Due to the weak financial strength of developing countries and the insufficient availability of domestic capital to support long-term investment, Chinese policy banks and state-owned banks ${ }^{13}$ participating in the OBOR have to play important roles in planning and implementation in major construction projects. With the support of state-owned bank loans, many Chinese state-owned companies have been actively engaged in the construction of overseas coal-fired power plants. International observers have warned that the lack of environmental and social protection standards adopted by China's financial institutions have contributed to increases in carbon emissions in host countries. Environmental groups and civil society organizations have expressed similar concerns about the impact of overseas loan projects by Chinese financial institutions. ${ }^{14}$ There is a need to enhance environmental and social protection governance in Chinese financial institutions to address environmental and social risk.

Development\%20of\%20Chinese\%20Enterprises\%20Overseas.pdf?download>, accessed May 25, 2017 [“Chinese Enterprises Overseas"].

${ }^{11}$ Denise Leung and Yingzhen Zhao, "Environmental and Social Policies in Overseas Investments: Progress and Challenges for China” (World Resources Institute: April 2013).

12 "List of Deliverables of the Belt and Road Forum for International Cooperation", <http://usa.chinadaily.com.cn/epaper/2017-05/16/content_29367726.htm>, accessed May 25, 2017. The list includes expanding the Silk Road Fund by 100 billion yuan. China Development Bank and China Export-Import Bank will provide 250 billion yuan and 130 billion yuan equivalent special RMB loans to support infrastructure construction, production capacity, and financial cooperation under the OBOR. The Ministry of Finance of China signed the memoranda of understanding on collaboration on matters of common interest under the Belt and Road Initiative with the Asian Development Bank, the Asian Infrastructure Investment Bank, the European Bank for Reconstruction and Development, the European Investment Bank, the New Development Bank, and the World Bank Group.

${ }^{13}$ In China, this term refers to three policy banks: the Agricultural Development Bank of China, China Development Bank, and China Export-Import Bank. China's policy banks are charged with policy lending in areas such as infrastructure projects, and with promoting foreign trade and diplomacy.

${ }^{14}$ Managing Environmental Impact: International Experience and Lessons in Risk Management for Overseas Investments, online: <https://www.wri.org/sites/default/files

managing_environmental_impact_international_experience_and_lessons_in_risk_management_for_overseas_invest ments.pdf>, accessed May 14, 2017. 


\section{A. The Definition of Green Finance}

"Green Finance" refers to the financial services provided for project investment and financing, project operation, and risk management in the fields of environmental protection, energy saving, emission reduction, and green technology. ${ }^{15}$ Mobilizing and shifting investments from carbonintensive sectors to green sectors with the help of enabling policy frameworks is at the centre of the green finance concept. Green finance requires financial institutions to integrate environmental and social protection as fundamental goals for lending decisions, ensuring the transparency of environmental information and measures, and facilitating oversight and accountability of the lending process. ${ }^{16}$ Generally, the promotion of green finance in financial institutions has two basic goals: to reach the goal of the self-sustainable development of financial institutions through the management of environmental risks and to guide capital towards investment in green industries, such as low carbon-emission and pollution governance industries, to promote the sustainable development of industries. ${ }^{17}$ Financial institutions should fully consider the external systemic risk, including the political, economic, and social security environment, in order to avoid lending and investment risks.

Chinese overseas investment funded by Chinese financial institutions has a long-term impact on a country's sustainable development and should undergo an in-depth analysis on related economic, social, and environmental repercussions. The Paris Climate Agreement also emphasizes the global response to the threat of climate change and aims to make "finance flows consistent with a pathway towards low greenhouse gas emissions and climate-resilient development." ${ }^{18}$ Hence, facilitating low-carbon and climate-resilient investment projects along the OBOR routes will become crucial for ensuring long-term sustainable development. Sustainable Development Goal (SDG) 7 of the 2030 Agenda also calls for ensuring access to affordable, reliable, sustainable, and modern energy for all by 2030. Chinese financial institutions can play an influential role to transfer of technology and financial resources from developed countries to developing countries to achieve SDGs.

\footnotetext{
${ }^{15}$ Ecological Finance Research Centre of Renmin University of China, "Green Finance for the Belt and Road Initiative" (China Financial Publication House: 2017).

${ }^{16}$ Jun Ma, "Establishing China’s Green Financial System" (China Financial Publication House: 2017).

${ }^{17}$ Hong Yin, "Green Finance Leads Green One Belt One Road Initiative" (China Banking Industry: 2017).

18 "Sustainable Energy for All”, online: <www.se4all.org>; "2030 Agenda for Sustainable Development", online: <sustainabledevelopment.un.org/post2015/transformingourworld>; "Paris Agreement", online: <unfccc.int/paris agreement/items/9485.php>.
} 
Safeguarding the sustainability of overseas projects is vital to ensure that the construction of infrastructure resource-efficient, low-carbon, socially inclusive and finally achieve the SDGs ${ }^{19}$ In achieving these objectives, financial institutions need to build capacity for countries to utilize this opportunity of investment and development to shift national economic structures towards inclusive green economies, using investment, trade, and macroeconomic policies as levers for change, and work towards achieving SDGs and the Paris Climate Agreement. ${ }^{20}$ Besides, the promotion of green development within financial institutions of credit management also help both China and countries along the OBOR route to adjust national and regional economic structure and development path, and achieve their sustainable development and climate objectives. Improvement in the environmental and social performance of Chinese overseas companies funded by Chinese financial institutions will in turn help promote sustainable investments in OBOR countries, improve relations between local peoples and foreign investors, and improve environmental and social justice.

\section{B. The Relationship between Environmental Risk and Financial Risk}

Financial institutions have come to realize that these risks are potential causes of volatile markets and financial instability. ${ }^{21}$ Considering potential changes in future environmental policy and law enforcement, non-performing asset ratios or loan default rates in high pollution risk industries such as steel, cement, and thermal power will rise accordingly. Green Finance is not only the key to the transition of the global economy towards sustainable and inclusive growth, it is also the key to guarantee the intrinsic elasticity and effectiveness of financial markets. As an innovative financial model based on the aim of environmental protection, green finance has become the new fulcrum of promoting economic transformation and industrial structural reform. ${ }^{22}$ Green finance can help the resource allocation of financial institutions to attract and guide social capital into new low

\footnotetext{
19 “Transforming Our World: The 2030 Agenda for Sustainable Development”, online: <https://sustainabledevelopment.un.org/post2015/transformingourworld>, accessed December 7, 2016.

${ }^{20} \mathrm{Ma}$, supra note 16.

${ }^{21}$ For an analysis of environmental risk in the financial sector in recent decades, see G20 Green Finance Study Group, "Environmental Risk Analysis by Financial Institutions: A Review of Global Practice" (UBP Leadership Institute, 2016), online:

<unepinquiry.org/wp-content/uploads/2016/09/2_Environmental_Risk_Analysis_by_Financial_Institutions.pdf >, accessed March 8, 2018.

${ }^{22}$ Yin, supra note 17.
} 
energy emission and low pollution technologies and industries to achieve economic transformation and development. ${ }^{23}$

With the increasing emphasis on combating climate change, the regulatory authorities of countries along the OBOR routes may intensify the monitoring, assessment, and management of environmental and social considerations. Ensuring the development of low-carbon and climateresilient infrastructure will be crucial for the long-term and sustainable development of the OBOR and the global economy. ${ }^{24}$ This necessity to shift towards a green economy has been reaffirmed by many different initiatives, and there is now a growing awareness of the potential growth prospects of transitioning to a green economy, including increased productivity, employment opportunities, tackling poverty and inequality, and attaining a cleaner environment and an improved quality of life. To promote sustainable development, many countries along the OBOR route have committed to undertake fundamental transformations in consumption and production processes and practices. The integration of green finance elements serves the long-term interests of Chinese investment institutions and the national sustainable development requirements of countries along the OBOR route. In addition, the Principles for Responsible Investment Initiative, which consists of a set of voluntary principles for asset owners and investment institutions, also requires financial institutions to incorporate environmental and social protection considerations into investment analysis and decision-making processes. ${ }^{25}$

Green finance has therefore become an important issue in financial innovation, global economic development, and environmental climate governance. The promotion of green finance can ensure the quality and sustainability of growth in the social and environmental spheres. ${ }^{26}$ Investment in overseas fossil fuel projects will pose a threat to financial institutions that provide financial support to these companies. The application of green financing standards would protect China's image as a responsible country and highlight its role as an increasingly active global power. With the rise

\footnotetext{
${ }^{23}$ Ecological Finance Research Centre of Renmin University of China (2017), Green Finance for the Belt and Road Initiative, China Financial Publication House.

${ }^{24}$ Bloomberg Brief, “One Belt, One Road: Assessing the Economic Impact of China's New Silk Road” (July 2, 2015), online: <https://issuu.com/davidhallusbct/docs/assessing_the_economic_impact_of_ch>, accessed October 18, 2015.

25 "The Principles for Responsible Investment Initiative", online: 〈www.unpri.org>, accessed March 8, 2015.

${ }^{26}$ Jing Gu, "China's New Silk Road to Development Cooperation: Opportunities and Challenges” (United Nations University Centre for Policy Research: 2015).
} 
of socially responsible investment, companies that have better environmental conservation practices for their business operations may have better chances of getting capital from private and multilateral financial institutions. ${ }^{27}$ The good performance of Chinese overseas companies will enhance Chinese financial institutions' role in global development cooperation and foster a positive image of these institutions as global citizens that take a low-carbon approach in overseas investment.

\section{The Role of Chinese Financial Institutions in Promoting Sustainable Overseas Development}

\section{A. Chinese and Chinese-lead Financial Institutions Participation in OBOR}

As most countries along the OBOR route are developing countries with little access to international financing to make up for infrastructure gaps and energy shortages, Chinese financial institutions play a vital role in providing financial support for project construction. Since its announcement of the OBOR, China has been making efforts to ensure the success of the program, not only through large-scale investment in the newly established Asian Infrastructure Investment Bank (AIIB), but also through the new Silk Road Fund and other bilateral agreements to finance the countries concerned to make up for the funding gap of OBOR construction. ${ }^{28}$ These financial institutions also help to design and implement policy frameworks that will ensure the investments are used to establish resource-efficient, low-carbon, and socially inclusive economic structures. The vast majority of loan finance of overseas companies and large infrastructure projects from China to countries along the OBOR is from China's official export credit agencies and policy banks, such as China Export-Import Bank (Eximbank), and state-owned banks, such as the Industrial and Commercial Bank of China. ${ }^{29}$ In addition, China's Ministry of Commerce is in charge of the

\footnotetext{
${ }^{27}$ Tao Hu, Yingzhen Zhao, Lihuan Zhou \& Denise Leung, "Managing Environmental Impact: International Experience and Lessons in Risk Management for Overseas Investments" (August 2014) World Resources Institute, online: <www.wri.org/managing-environmental-impact-international-experience-and-lessons-in-risk-managementfor-overseas-investments>, accessed March 8, 2018.

28 “China's Development Financing under the 'Belt and Road' Initiative” (March 23, 2017), online: <www.ghub.org/blog/archives/7143>, accessed March 8, 2018 [“China’s Development Financing”].

${ }^{29}$ EY Knowledge (Global Markets), supra note 7.
} 
Department of Foreign Aid, which oversees projects financed through zero-interest loans and grants and signs off on China Eximbank's concessional loans. ${ }^{30}$

With the acceleration of economic globalization and the continued strengthening of international financial cooperation, financial institutions are participating in overseas construction and investment in various ways. In general, the relevant financial institutions that provide financial support for the construction of OBOR projects can be divided into three categories: regional multilateral development financial institutions including the Asian Infrastructure Investment Bank, the New Development Bank, and the Asian Development Bank; national policy and development banks, including China Development Bank and China Export-Import Bank; state-owned commercial banks, such as the People's Bank of China and the Industrial and Commercial Bank of China; and insurance investment funds, such as the ASEAN Investment Cooperation Fund and Silk Road funds to provide strong financial support and promote OBOR infrastructure, resource development, and production capacity. The financial institutions and their general functions in OBOR are summarized and listed below.

\section{Financial Institutions Participating in OBOR}

\begin{tabular}{|c|c|l|}
\hline $\begin{array}{c}\text { Multilatera } \\
\text { I Financial } \\
\text { Institution } \\
\text { Developme } \\
\text { nt Banks }\end{array}$ & $\begin{array}{c}\text { The Asian } \\
\text { Infrastructure } \\
\text { Investment } \\
\text { Bank }\end{array}$ & $\begin{array}{l}\text { Regional financial institution, with registered capital of 100 billion US } \\
\text { dollars. By December 2016, AIIB had approved nine infrastructure projects } \\
\text { involving a total investment of 1.73 billion US dollars along the Belt and } \\
\text { Road. }\end{array}$ \\
\cline { 2 - 4 } & $\begin{array}{c}\text { New } \\
\text { Development } \\
\text { Bank }\end{array}$ & $\begin{array}{l}\text { Regional financial institution, established in 2014 with a total of 100 billion } \\
\text { US dollars in funds and a further 100 billion US dollars in currency reserves } \\
\text { committed to financing infrastructure projects in developing countries } \\
\text { mainly from the five BRIC countries and other developing countries in } \\
\text { infrastructure construction. It announced the first batch of loan projects in } \\
\text { April 2016. }\end{array}$ \\
\cline { 2 - 5 } & $\begin{array}{c}\text { Asian } \\
\text { Development } \\
\text { Bank }\end{array}$ & $\begin{array}{l}\text { Regional financial institution, participate in OBOR projects through joint } \\
\text { investment with the ADB and BRIC. }\end{array}$ \\
\hline $\begin{array}{c}\text { Chinese } \\
\text { National } \\
\text { Policy } \\
\text { Banks }\end{array}$ & $\begin{array}{c}\text { China } \\
\text { Development } \\
\text { Bank }\end{array}$ & $\begin{array}{l}\text { Provides strategic planning consulting, project incubation and other } \\
\text { integrated financial services. Has signed more than 70 cooperation } \\
\text { agreements with more than 60 countries, involving 900 projects on } \\
\text { transportation, energy, resources and other industries, with a total investment } \\
\text { of more than 800 billion US dollars. }\end{array}$ \\
\hline
\end{tabular}

\footnotetext{
${ }^{30}$ Jyhjong Hwang, Deborah Brautigam \& Janet Eom, "How Chinese Money is Transforming Africa: It's Not What You Think" (2016), online:

〈http://www.africa-platform.org/resources/how-chinese-money-transforming-africa-its-not-what-you-think〉, accessed December 6, 2016.
} 


\begin{tabular}{|c|c|c|}
\hline & $\begin{array}{l}\text { China } \\
\text { Export-Import } \\
\text { Bank }\end{array}$ & $\begin{array}{l}\text { Provided loans for more than } 1,000 \text { projects in } 49 \text { countries, including roads, } \\
\text { railways, ports construction, electricity, communications industries etc. }\end{array}$ \\
\hline \multirow{4}{*}{$\begin{array}{l}\text { National } \\
\text { Commercia } \\
\text { l Banks }\end{array}$} & $\begin{array}{l}\text { People's Bank of } \\
\text { China }\end{array}$ & $\begin{array}{l}\text { As of the end of 2016, the bank has set up branches in } 16 \text { countries along } \\
\text { the OBOR, followed by about } 300 \text { major foreign projects with a total } \\
\text { investment of more than } 250 \text { billion US dollars. }\end{array}$ \\
\hline & $\begin{array}{l}\text { Industrial and } \\
\text { Commercial } \\
\text { Bank of China } \\
\quad(\text { ICBC })\end{array}$ & $\begin{array}{l}\text { Head office of ICBC sets up OBOR business development leadership group } \\
\text { to promote the implementation of OBOR investment projects. }\end{array}$ \\
\hline & $\begin{array}{l}\text { China } \\
\text { Infrastructure } \\
\text { Bank }\end{array}$ & $\begin{array}{l}\text { Has accumulated } 268 \text { major projects in OBOR countries, with an investment } \\
\text { of about } 460 \text { billion US dollars, involving major industries such as electricity, } \\
\text { construction, mineral, transportation, oil and gas, and communications. }\end{array}$ \\
\hline & $\begin{array}{l}\text { Agricultural } \\
\text { Bank of China }\end{array}$ & $\begin{array}{l}\text { Will match } 15.4 \text { billion US dollars of credit to support Xinjiang Silk Road } \\
\text { economic zone core area construction. }\end{array}$ \\
\hline \multirow{7}{*}{ Funds } & Silk Road Fund & $\begin{array}{l}\text { Founded in 2014, with capital of } 40 \text { billion US dollars with investment from } \\
\text { China Investment Co., Ltd., China Export-Import Bank and China } \\
\text { Development Bank to support OBOR investment projects in infrastructure, } \\
\text { resource development, production and financial cooperation and other fields. }\end{array}$ \\
\hline & $\begin{array}{l}\text { China Insurance } \\
\text { Investment Fund }\end{array}$ & $\begin{array}{l}\text { Limited partnership with } 300 \text { billion RMB from insurance agencies to } \\
\text { provide investment funds. The first phase of } 40 \text { billion yuan fund has been } \\
\text { invested in OBOR projects }\end{array}$ \\
\hline & $\begin{array}{l}\text { China-ASEAN } \\
\text { Investment } \\
\text { Cooperation } \\
\text { Fund }\end{array}$ & $\begin{array}{l}\text { China Export-Import Bank as the main issuer, together with a number of } \\
\text { domestic and foreign investment institutions mainly invest in infrastructure, } \\
\text { energy and natural resources in the ASEAN region, including transportation, } \\
\text { electricity, renewable resources, public utilities, telecommunications } \\
\text { infrastructure, pipeline storage and transportation, public facilities, minerals, } \\
\text { oil, gas, etc. }\end{array}$ \\
\hline & $\begin{array}{l}\text { China Central } \\
\text { and Eastern } \\
\text { European Fund }\end{array}$ & $\begin{array}{l}\text { Built in } 2013 \text { with limited partners including the Export-Import Bank of } \\
\text { China, the Hungarian Export-Import Bank and the Investment Advisory } \\
\text { Team to support investment in Central and Eastern Europe }\end{array}$ \\
\hline & $\begin{array}{l}\text { China-Europe } \\
\text { Asian } \\
\text { Cooperation } \\
\text { Fund }\end{array}$ & $\begin{array}{l}\text { Built by the China Export-Import Bank and the Bank of China, it covers } \\
\text { industries relating to agricultural development, infrastructure, technology, } \\
\text { and manufacturing in Europe and Asia. The fund will play an active role in } \\
\text { promoting the construction of the Silk Road economic zone, deepening } \\
\text { cooperation with Eurasian countries and promoting economic and social } \\
\text { development in Europe and Asia }\end{array}$ \\
\hline & $\begin{array}{l}\text { Silk Road } \\
\text { Investment Fund }\end{array}$ & $\begin{array}{l}\text { Shandong Gold Group owns shares } 35 \% \text {, Shaanxi Gold Group } 25 \% \text {, the } \\
\text { remaining shares scattered to other financial institutions. Plans to raise } 16 \\
\text { billion US dollars to invest in gold mining and related businesses in the Silk } \\
\text { Road nation in 5-7 years. }\end{array}$ \\
\hline & $\begin{array}{l}\text { Green Eco Silk } \\
\text { Road Investment } \\
\text { Fund }\end{array}$ & $\begin{array}{l}\text { Common equity fund with a total size of } 30 \text { billion RMB. Targeted industries } \\
\text { include solar energy construction, clean energy development and ecological } \\
\text { restoration, ecological agriculture, and other ecological industries }\end{array}$ \\
\hline
\end{tabular}

Author's Compilation 


\section{B. China's Policy Support to Promote Green Finance}

Chinese financial institutions are important financing supports for OBOR investment projects which promote significant economic benefits to investment recipient countries. ${ }^{31}$ However, the focus of international attention and discussion has become whether governance of Chinese financial institutions has adequately adapted to promote environmental and social risk management and a responsible attitude toward corporations' ecological footprint. ${ }^{32}$ In response to the criticisms, building a green financial system has become China's national strategy, and this has gradually improved regulation of Chinese financial institutions' social and environmental performance overseas. ${ }^{33}$ Green finance was included for the first time in China's ecological civilization programmatic documents for national economic and social development. ${ }^{34}$ The G20 summit passed the first "G20 Green Finance General Report" and urged multilateral banks to incorporate the social and environmental impacts of projects into high-quality infrastructure investment considerations. ${ }^{35}$ Chinese financial institutions are increasingly taking good environmental and social performance into consideration in making lending decisions. A series of measures was introduced to support the development of green finance, including the sustainable credit principle and responsibility investment principle; the promotion of environmental information disclosure and governance requirements; and the introduction of green loans, green financial products (such as bonds), green infrastructure investment trusts, and Green index

\footnotetext{
31 "Chinese Development Overseas", supra note 28.

32 Chan-Fishel, Michelle, "Time to Go Green: Environmental Responsibility in the Chinese Banking Sector" (May 2007) Friends of the Earth-US and Bank Track, online: < https://www.banktrack.org/download/time_to_go_green_environmental_responsibility_in_the_chinese_banking_sec tor/0_0_070509_chinese_bank_public_report_final.pdf>, accessed December 10, 2017.

${ }^{33}$ Friends of the Earth, "China Development Bank's outward investments: An assessment of environmental and social policies and practices" (July 2012), online: <http://ef.amazonia. org.br/wp-content/uploads/2012/07/china_ development_bank.pdf>, accessed June 7, 2016.

34 China Council for International Cooperation on Environment and Development, "South-South Cooperation for Ecological Civilization" (Draft) (December 2016), online:

<http://www.cciced.net/cciceden/POLICY/rr/prr/2016/201612/P020161214521504952840.pdf〉, accessed January $25,2017$.

${ }^{35}$ G20 Green Finance Study Group, "2017 G20 Green Finance Synthesis Report” (July 2017), online: <http://unepinquiry.org/wp-content/uploads/2017/07/2017_GFSG_Synthesis_Report_EN.pdf>, accessed December 2, 2017. The 2nd session of the Group of 20 Ministers of Energy (G20) formally adopted the G20 Voluntary Action Plan on Renewable Energy to encourage countries to accelerate the development of renewable energy.
} 
products. ${ }^{36}$ The development of green finance policies involves the powers and responsibilities of multiple subjects, including the People's Bank of China, China Banking Regulatory Commission, China Securities Regulatory Commission, China Insurance Regulatory Commission, and the National Development and Reform Commission. ${ }^{37}$ The following table introduces the efforts of Chinese government in improving the regulation of Chinese companies' social and environmental performance overseas from 2007 to 2017.

Chines Government's Efforts to Integrate Environmental and Social Considerations into Lending

\begin{tabular}{|l|l|l|l|}
\hline \multicolumn{1}{|c|}{$\begin{array}{c}\text { Issue } \\
\text { Time }\end{array}$} & $\begin{array}{l}\text { Name of Regulation } \\
\text { and Policy }\end{array}$ & \multicolumn{1}{|c|}{ Issuing Agents } & \multicolumn{1}{c|}{ Main Contents } \\
\hline $\begin{array}{l}\text { May } \\
\mathbf{2 0 0 7}\end{array}$ & $\begin{array}{l}\text { Guidelines on } \\
\text { Compliance Risk } \\
\text { Management of } \\
\text { Commercial Banks }\end{array}$ & $\begin{array}{l}\text { China Banking Regulatory } \\
\text { Commission }\end{array}$ & $\begin{array}{l}\text { Requires commercial banks to take into } \\
\text { consideration the interrelatedness } \\
\text { between compliance risk and credit risk, } \\
\text { market risk, operational risk, and other } \\
\text { risks, so as to ensure the consistency of } \\
\text { different risk management policies and } \\
\text { procedures. }\end{array}$ \\
\hline July 2007 & $\begin{array}{l}\text { Opinions on } \\
\text { Implementing } \\
\text { Environmental } \\
\text { Protection Policies and } \\
\text { Regulations to Prevent } \\
\text { Credit Risks }\end{array}$ & $\begin{array}{l}\text { People's Bank of China and } \\
\text { China Banking Regulatory }\end{array}$ & $\begin{array}{l}\text { Requires environmental protection } \\
\text { bureaus and financial institutions at all } \\
\text { levels to fully understand the significance } \\
\text { of credit policies as tools for } \\
\text { environmental protection, and to } \\
\text { strengthen environmental monitoring and } \\
\text { credit management of construction } \\
\text { projects and enterprises. }\end{array}$ \\
\hline $\begin{array}{l}\text { January } \\
\text { 2009 }\end{array}$ & $\begin{array}{l}\text { Guidance on Social } \\
\text { Responsibility of } \\
\text { Chinese Banking } \\
\text { Financial Institutions }\end{array}$ & China Banking Association & $\begin{array}{l}\text { Proposes to establish a green financial } \\
\text { system and stress the importance of } \\
\text { financial institutions in fulfilling } \\
\text { corporate social and environmental } \\
\text { responsibility goals. }\end{array}$ \\
\hline
\end{tabular}

\footnotetext{
36 Jing Zheng, et. al., “The Construction of Green Finance to Support Green One Belt One Road Investment, Environmental Protection” (2017) 19 Environmental Protection. (郑竟等，一带一路绿色投融资机制构建探讨， 环境保护，2017 年第 19 期)。

${ }^{37}$ Leung \& Zhao, supra note 11.
} 


\begin{tabular}{|c|c|c|c|}
\hline $\begin{array}{l}\text { Issue } \\
\text { Time }\end{array}$ & $\begin{array}{l}\text { Name of Regulation } \\
\text { and Policy }\end{array}$ & Issuing Agents & Main Contents \\
\hline $\begin{array}{l}\text { May } \\
2011\end{array}$ & $\begin{array}{l}\text { Circular on Full } \\
\text { Implementation of } \\
\text { Green Credit Policies } \\
\text { and Further } \\
\text { Improvement of } \\
\text { Information Sharing }\end{array}$ & $\begin{array}{l}\text { China's Environmental } \\
\text { Protection Agency and the } \\
\text { People's Bank of China }\end{array}$ & $\begin{array}{l}\text { Requires environmental protection } \\
\text { authorities and financial institutions at all } \\
\text { levels to fully understand the importance } \\
\text { of establishing a mechanism for sharing } \\
\text { information on green credit, and make use } \\
\text { of the Credit Reference Center of the } \\
\text { People's Bank of China as a platform to } \\
\text { share environmental information, and } \\
\text { prescribe as well as the respective } \\
\text { responsibilities of environmental } \\
\text { protection authorities and financial } \\
\text { institutions. }\end{array}$ \\
\hline $\begin{array}{l}\text { February } \\
2012\end{array}$ & $\begin{array}{l}\text { Guidance on Green } \\
\text { Loans }\end{array}$ & $\begin{array}{l}\text { China Banking Regulatory } \\
\text { Commission }\end{array}$ & $\begin{array}{l}\text { Defines the meaning and scope of } \\
\text { environmental and social risks to promote } \\
\text { financial institutions to adjust credit } \\
\text { structure through green credit to prevent } \\
\text { investment risks stipulating that banking } \\
\text { financial institutions shall increase their } \\
\text { support to the green, low-carbon economy } \\
\text { and adopt stronger environmental and } \\
\text { social risk management for clients. }\end{array}$ \\
\hline $\begin{array}{l}\text { Decembe } \\
\text { r } 2014\end{array}$ & $\begin{array}{l}\text { Assessment Criteria of } \\
\text { Green Loans and } \\
\text { Green Loans } \\
\text { Implementation }\end{array}$ & $\begin{array}{l}\text { China Banking Regulatory } \\
\text { Commission }\end{array}$ & $\begin{array}{l}\text { Prescribes environmental and social } \\
\text { assessment criteria for overseas projects. }\end{array}$ \\
\hline $\begin{array}{l}\text { February } \\
2013\end{array}$ & $\begin{array}{l}\text { Guidance on } \\
\text { Environmental } \\
\text { Protection during } \\
\text { Foreign Investment } \\
\text { and Corporation }\end{array}$ & $\begin{array}{l}\text { China Ministry of } \\
\text { Commerce and } \\
\text { Environmental Protection } \\
\text { Agency }\end{array}$ & $\begin{array}{l}\text { Guides Chinese enterprises to standardize } \\
\text { environmental protection behavior in } \\
\text { foreign investment, and guide enterprises } \\
\text { to fulfill the social responsibility of } \\
\text { environmental protection in order to } \\
\text { promote the sustainable development of } \\
\text { foreign investment. }\end{array}$ \\
\hline $\begin{array}{l}\text { Decembe } \\
\text { r } 2016\end{array}$ & $\begin{array}{l}\text { The } 13^{\text {th }} \text { Five-Year } \\
\text { Plan on Eco- } \\
\text { Environmental } \\
\text { Protection }\end{array}$ & China State Council & $\begin{array}{l}\text { Overall plan for the reform of ecological } \\
\text { civilization system with a clear proposal } \\
\text { to develop green finance. }\end{array}$ \\
\hline $\begin{array}{l}\text { April } \\
2017\end{array}$ & $\begin{array}{l}\text { Guidance on } \\
\text { Promoting Green One } \\
\text { Belt One Road }\end{array}$ & $\begin{array}{l}\text { China Foreign Affairs } \\
\text { Agency, China } \\
\text { Environmental Protection } \\
\text { Agency, National } \\
\text { Development and Reform } \\
\text { Commission, Commerce } \\
\text { Department }\end{array}$ & $\begin{array}{l}\text { General guidelines on promoting a green } \\
\text { OBOR. }\end{array}$ \\
\hline
\end{tabular}




\begin{tabular}{|c|c|c|c|}
\hline $\begin{array}{l}\text { Issue } \\
\text { Time }\end{array}$ & $\begin{array}{l}\text { Name of Regulation } \\
\text { and Policy }\end{array}$ & Issuing Agents & Main Contents \\
\hline $\begin{array}{l}\text { May } \\
2017\end{array}$ & $\begin{array}{l}\text { OBOR Eco- } \\
\text { Environmental } \\
\text { Protection Cooperation } \\
\text { Planning }\end{array}$ & $\begin{array}{l}\text { China Environmental } \\
\text { Protection Agency }\end{array}$ & $\begin{array}{l}\text { Proposes a green financial policy } \\
\text { formulation which explores the } \\
\text { establishment of green investment and } \\
\text { financing management standards, the } \\
\text { establishment of a green development } \\
\text { fund, and the development of } \\
\text { environmental risk management tools. }\end{array}$ \\
\hline $\begin{array}{l}\text { August } \\
2016\end{array}$ & $\begin{array}{l}\text { Guidance on Building } \\
\text { Green Finance System }\end{array}$ & $\begin{array}{l}\text { People's Bank of China, } \\
\text { Ministry of Finance, } \\
\text { National Development and } \\
\text { Reform Commission, China } \\
\text { Environmental Protection } \\
\text { Agency, China Banking } \\
\text { Regulatory Commission, } \\
\text { China Securities Regulatory } \\
\text { Commission, China } \\
\text { Insurance Commission }\end{array}$ & $\begin{array}{l}\text { Consists of } 35 \text { Articles which outline the } \\
\text { future of China's green financial system. } \\
\text { It expresses the official definition of } \\
\text { green finance for the first time. It supports } \\
\text { Chinese financial institutions and } \\
\text { enterprises to issue green bonds abroad, } \\
\text { and guide international funds to invest in } \\
\text { our green bonds, green stocks and other } \\
\text { green financial assets, and encourage the } \\
\text { establishment of joint venture green } \\
\text { development fund. }\end{array}$ \\
\hline $\begin{array}{l}\text { April } \\
2017\end{array}$ & $\begin{array}{l}\text { Guidance on } \\
\text { Promoting Green One } \\
\text { Belt One Road }\end{array}$ & $\begin{array}{l}\text { China Foreign Affairs } \\
\text { Agency, China } \\
\text { Environmental Protection } \\
\text { Agency, National } \\
\text { Development and Reform } \\
\text { Commission, Ministry of } \\
\text { Commerce }\end{array}$ & $\begin{array}{l}\text { General guideline on promoting a green } \\
\text { OBOR. }\end{array}$ \\
\hline $\begin{array}{l}\text { May } \\
2017\end{array}$ & $\begin{array}{l}\text { OBOR Eco- } \\
\text { Environmental } \\
\text { Protection Cooperation } \\
\text { Planning }\end{array}$ & $\begin{array}{l}\text { China Environmental } \\
\text { Protection Agency }\end{array}$ & $\begin{array}{l}\text { Proposes the promotion of finance policy } \\
\text { and guidelines. }\end{array}$ \\
\hline $\begin{array}{l}\text { Septembe } \\
\text { r } 2017\end{array}$ & $\begin{array}{l}\text { Environmental Risk } \\
\text { Management Initiative } \\
\text { for China's Overseas } \\
\text { Investment }\end{array}$ & $\begin{array}{l}\text { The Green Finance } \\
\text { Committee (GFC) of China } \\
\text { Society for Finance and } \\
\text { Banking, Investment } \\
\text { Association of China (IAC), } \\
\text { China Banking Association } \\
\text { (CBA), Asset Management } \\
\text { Association of China } \\
\text { (AMAC), Insurance Asset } \\
\text { Management Association of } \\
\text { China (IAMAC), China } \\
\text { Trustee Association (CTA), } \\
\text { and the Foreign Economic } \\
\text { Cooperation Office (FECO) } \\
\text { of the Ministry of } \\
\text { Environment Protection }\end{array}$ & $\begin{array}{l}\text { Consists of } 12 \text { articles on the disclosure } \\
\text { of environmental and social governance } \\
\text { information, green finance, and } \\
\text { environmental and social protection } \\
\text { standards overseas to improve institutions } \\
\text { and companies' capacity for } \\
\text { environmental risk management overseas. } \\
\text { The regulation especially emphasizes the } \\
\text { importance of financial institutions in } \\
\text { complying with regulations in China and } \\
\text { host countries, with prevailing } \\
\text { international standards, and with the } \\
\text { adoption of the highest standards where } \\
\text { possible. }\end{array}$ \\
\hline
\end{tabular}

Author's Compilation 


\section{Commitment to Sustainable Lending and Investment: Environmental and Social Protection Framework of Chinese Financial Institutions}

Concerned with reputational damage caused by mounting controversies on environmental and social performance, Chinese financial institutions have realized that lending and investment policies that take into account the protection of the natural and social environment serve their best interests. Chinese financial institutions are gradually improving their own institutional systems through the inclusion of environmental and social risk requirements, and through incorporating risk assessment and management systems as a necessary and important consideration in the lending process. ${ }^{38}$ Chinese financial institutions have signed up with a number of internationally environmental and social standards as well as regional industry-specific initiatives, such as expanding cooperation with the United Nations Environment Program, the World Bank, the Asian Development Bank, and other multilateral international organizations and international nongovernmental organizations. ${ }^{39}$ The adaptation of Chinese financial institutions' systematic environmental social security system not only serves the national sustainable development strategy, but also establishes the benchmark for the international developing financial institutions that contribute to the environmental social governance of other countries in overseas investment and financing activities. By paying attention to the ecological footprint and social impact of their own investment and financing activities, the contribution of Chinese financial institutions' social and economic development will have an important impact on the economic and social development of developing countries to more effectively meet the challenges of SDGs and promote a sustainable development model for inclusive global economic growth.

China Exim Bank and China Development Bank, the major channels for financing foreign investments of Chinese companies, developed their own environmental policy and impact assessments. The China Exim Bank, the China Development Bank, the China Industrial and Commercial Bank, and the Bank of China have also adopted the Equator Principles on green credit policies. ${ }^{40}$ In addition, several Chinese financial institutions and environmental agencies, such as the Industrial Bank of China, People's Bank of China, and Ministry of Environmental Protection,

\footnotetext{
${ }^{38}$ Friends of the Earth, supra note 33.

39 Jing Zheng, et.al., supra note 36.

40 Jun Ma, Establishing China’s Green Financial System, China Financial Publication House, 2017 (马俊, 构建中国 绿色金融体系, 中国金融出版社, 2017。
} 
are adopting sustainability criteria for credit provision to Chinese overseas companies (see chart below). These measures will strengthen the role of multilateral development of financial institutions in high-quality infrastructure investment. The chart below shows the general environmental and social governance frameworks of the Chinese financial institutions involved in OBOR. There are many differences among the different institutions. Compared to commercial financial institutions, Chinese policy banks have a more comprehensive safeguard framework to protect local environments and social conditions in host countries.

\section{Environmental and Social Governance Frameworks of Financial Institutions in China}

\begin{tabular}{|l|l|}
\hline \multicolumn{1}{|c|}{ Financial Institution } & \multicolumn{1}{c|}{ Framework } \\
\hline $\begin{array}{l}\text { Asian Infrastructure } \\
\text { Investment Bank }\end{array}$ & Issued its "Environment and Social Security Framework"41 in 2016. \\
\hline New Development Bank & Issued its "Environment and Social Security Framework"42 in 2016. \\
\hline China Development Bank & $\begin{array}{l}\text { Joined the United Nations Environment Program Financial Initiative (UNEP FI) } \\
\text { and required the bank to comply with relevant international norms and national } \\
\text { policies. There is no public disclosure of environmental and social security } \\
\text { policies. }\end{array}$ \\
\hline China Export-Import Bank & $\begin{array}{l}\text { No specific safeguard policy. Issued "China Export-Import Bank Environmental } \\
\text { and Social Evaluation Guidance on Loans" in 2008 which requires overseas } \\
\text { project developers to complete an environmental and social impact assessment } \\
\text { before approving the loan. Issued "China Export-Import Bank Green Credit } \\
\text { Guideline“ in 2015 to provide specific requirements for strengthening } \\
\text { environmental and social risk management of credit projects in the aspects of } \\
\text { organization and management, policy system, process management, internal } \\
\text { control management, and information disclosure. }\end{array}$ \\
\hline People's Bank of China & $\begin{array}{l}\text { No specific safeguard policy. Comply with Environmental Information } \\
\text { Disclosure Guidelines for Listed Companies of Shanghai Stock Exchange; } \\
\text { Environmental, Social and Governance Reporting Guideline of the Hong Kong } \\
\text { Stock Exchange; and the Global Sustainability Development Report Guideline of } \\
\text { International Organization for Standardization. }\end{array}$ \\
\hline
\end{tabular}

\footnotetext{
${ }^{41}$ Asian Infrastructure Investment Bank, "Environmental and Social Framework” (February 2016), online: <https://www.aiib.org/en/policies-strategies/_download/environment-framework/20160226043633542.pdf〉, accessed on October 20, 2017.

${ }^{42}$ New Development Bank, "Environmental and Social Framework" (March, 2016), online: <https://www.ndb.int/wp-content/uploads/2017/02/ndb-environment-social-framework-20160330.pdf>, accessed August 8, 2017.
} 


\begin{tabular}{|c|c|}
\hline Financial Institution & Framework \\
\hline $\begin{array}{l}\text { Industrial and Commercial } \\
\text { Bank of China }\end{array}$ & $\begin{array}{l}\text { Joined the Equator Principles (EPs) and the Carbon Disclosure Project (CDP), } \\
\text { UN Global Compact committed to good practice industry initiatives such as the } \\
\text { UN Environment Finance Initiative and the UN Principles for Responsible } \\
\text { Investment. Implemented the "Green Credit Guidelines" and "Green Credit } \\
\text { Evaluation Indicators" to provide a more stringent standard for financial } \\
\text { institutions to carry out domestic and overseas infrastructure operations to control } \\
\text { environmental and social risks. However, this guideline does not specify whether } \\
\text { it is only applicable to domestic financing or whether it also applies to overseas } \\
\text { investment lenders. }\end{array}$ \\
\hline China Construction Bank & No specific safeguard policy. \\
\hline Silk Road Fund & $\begin{array}{l}\text { Has not yet established a set of comprehensive, systematic environmental social } \\
\text { risk assessment and management standards or policies. Its environmental and } \\
\text { social risk management can only be analyzed through its investment and } \\
\text { financing projects. }\end{array}$ \\
\hline Silk Road Gold Fund & $\begin{array}{l}\text { Pay attention to green and sustainable development and actively assume social } \\
\text { responsibility. }\end{array}$ \\
\hline $\begin{array}{l}\text { Green Silk Road Equity } \\
\text { Investment Fund }\end{array}$ & $\begin{array}{l}\text { No specific safeguard policy. Committed to the Silk Road economic zone for } \\
\text { green industry investment, promote the Silk Road along the country and region } \\
\text { to improve the ecological environment and the development of green economy. }\end{array}$ \\
\hline $\begin{array}{l}\text { China - ASEAN Investment } \\
\text { Cooperation Fund }\end{array}$ & $\begin{array}{l}\text { Focuses on the sustainable development of potential investment projects and uses } \\
\text { the environmental and social standards advocated by the World Bank to regulate } \\
\text { the environmental performance of its investment projects. }\end{array}$ \\
\hline $\begin{array}{l}\text { China Insurance Investment } \\
\text { Fund }\end{array}$ & No specific safeguard policy. \\
\hline $\begin{array}{l}\text { China Agricultural Bank of } \\
\text { China Investment } \\
\text { Corporation }\end{array}$ & $\begin{array}{l}\text { Issued Agricultural Bank of China Implementation Guideline on green financial } \\
\text { credit. No specific safeguard policy. }\end{array}$ \\
\hline China Investment Co., Ltd. & No specific safeguard policy. \\
\hline CITIC Co., Ltd & No specific safeguard policy. \\
\hline
\end{tabular}

\section{Environmental and Social Framework Comparison}

After decades of practice and development, the environmental and social protection framework of multilateral financial institutions has improved standards and provisions on environmental and social standards, pre-assessment, implementation, post facto assessment, information disclosure, and complaint mechanisms for financed projects. In general, the environmental and social safeguard policies of multilateral financial institutions are relatively well-developed. The Ministry of Finance of China has signed memoranda of understanding on collaboration on matters of common interest under OBOR with the Asian Development Bank, the Asian Infrastructure 
Investment Bank, and the World Bank Group. ${ }^{43}$ The effective acquisition of new knowledge based on existing experience and practice, and integration of climate and social risks along the OBOR is vital for Chinese financial institutions.

\section{A. Environmental and Social Protection Frameworks of Multinational Financial}

\section{Institutions}

Environmental and social protection frameworks of multinational financial institutions are welldeveloped in terms of detailed environmental and social risk management regulations for project financing and complaints and supervision mechanisms. The protection policies of multilateral development banks generally involve gender, labour rights, community health, property safety, personal safety, ecosystem protection, climate change, human rights, environmental and social assessment and governance programs, involuntary migration, etc. They can also assist developing countries through policy dialogue, sharing experience, and identifying best practices and help strengthen capacity in developing countries that lack regulatory capacity or even basic governance systems. Global voluntary sustainable investment guidelines, such as the Equator Principles, the United Nations Global Compact, and the Global Reporting Initiative provide a reference for international investors and financial institutions to develop internal and project-based environmental and social risk management systems. ${ }^{44}$ This section focuses on the environmental and social policies of multilateral financial institutions and provides a brief analysis of their management systems and mechanisms. Multilateral development banks such as the World Bank, Asian Development Bank, and Asian Infrastructure Investment Bank have been working on the development and implementation of relatively mature environmental and social security systems, information disclosure policies, and dispute resolution mechanisms. Chinese financial institutions can not only learn about the environmental and social risk management policies of the multilateral development banks, but also learn best practices directly by leading large-scale projects jointly with these institutions.

\footnotetext{
${ }^{43}$ China Daily USA, "List of Deliverables of the Belt and Road Forum for International Cooperation" (May 16, 2017) China Daily, online: <usa.chinadaily.com.cn/epaper/2017-05/16/content_29367726.htm>, accessed May 25, 2017.

44 The three global initiatives set out standard guidance and requirements for incorporating environmental and social-related covenants into loan documentation and for monitoring the environmental and social performance of project finance transactions throughout the life of the loan.
} 


\section{a. The World Bank Group}

As an international multilateral financial institution, the World Bank has a complete operational policy for the projects it supports, which can effectively ensure the economic, financial, social, and environmental viability of the bank's projects and activities. The World Bank Group Environmental, Health, and Safety Guidelines are technical reference documents with general and industry-specific examples of good international industry practice. ${ }^{45}$ The security policy is composed of both an environmental assessment policy and policies designed to prevent unintended negative impacts on third parties and the environment. It deals with natural habitats, corruption, cultural property, involuntary migration, ethnic minorities, dam safety, projects implemented on international waterways, and projects in disputed areas in its four environmental social security requirements. ${ }^{46}$ In terms of combating climate change and guiding sustainable investment, the World Bank committed to providing support to more than 180 countries to help them achieve their national contributions, and launched the climate change action plan to further integrate climate change elements into their lending projects, and provide finance and technical assistance for green low-carbon transition. ${ }^{47}$

As a member of the World Bank Group, the International Finance Corporation (IFC) has developed its own Sustainability Framework and this has become an integral part of IFC's approach to risk management. ${ }^{48}$ The Sustainability Framework comprises IFC's Policy and Performance Standards on Environmental and Social Sustainability and IFC's Access to Information Policy. The eight Performance Standards cover the following areas: assessment and management of environmental and social risks and impacts; labour and working conditions; resource efficiency and pollution control; community health, safety and security; land acquisition and involuntary migration;

\footnotetext{
${ }^{45}$ World Bank, "World Bank Group Environmental, Health, and Safety Guidelines", online: <http://www.ifc.org/wps/wcm/connect/topics_ext_content/ifc_external_corporate_site/sustainability-at-ifc/policiesstandards/ehs-guidelines >, accessed March 20, 2018.

${ }^{46}$ World Bank, "World Bank Policy on Disclosure of Information" (2002), online: <http://siteresources.worldbank.org/OPSMANUAL/Resources/DisclosurePolicy.pdf>, accessed March 8, 2018 at paras $40-42$.

${ }^{47}$ World Bank, "World Bank Group Sets New Course to Help Countries Meet Urgent Climate Challenges" (April 7, 2016), online:http://www.worldbank.org/en/news/feature/2016/04/07/world-bank-group-sets-new-course-to-helpcountries-meet-urgent-climate-challenges>, accessed October 8, 2017

${ }^{48}$ International Finance Corporation, "IFC's Sustainability Framework" (January 2012), online: <https://www.ifc.org/wps/wcm/connect/b9dacb004a73e7a8a273fff998895a12/IFC_Sustainability_+Framework.pdf ?MOD=AJPERES>, accessed September 17, 2016
} 
biodiversity conservation; and sustainable management of biological resources, indigenous peoples, and cultural heritage. The environmental and social management of financed projects should include policies, identification of risks and impacts, management plans, organizational capabilities and qualifications, early warning and response measures, stakeholder participation, monitoring, and review. The IFC has also developed a grievance mechanism. Those affected by Chinese financed projects can file complaints to a Compliance Advisor/Ombudsman, an independent oversight authority that reports directly to the president of the World Bank Group and that thus ascertains application of the IFC Standards to companies, and dealing specifically with complaints with three functions of dispute resolution, compliance investigation, and consultancy. ${ }^{49}$

\section{b. The Asian Development Bank}

The Asian Development Bank (ADB) has developed detailed information disclosure, complaints and accountability mechanisms. ${ }^{50}$ Addressing climate change is one of the priorities of the ADB's social and environmental safeguard framework. In its 2008-2020 long-term strategic framework, the ADB has established environmental sustainability as one of the strategic agendas of business. The bank developed a Climate Investment Fund, a Clean Technology Fund and several multicarbon funds to support the establishment and development of international and national carbon markets, and provide financial support to poor countries to help them reduce greenhouse gas emissions to adapt to climate change. ${ }^{51} \mathrm{With}$ regard to environmental and social risk management, the ADB described in detail its Policy on involuntary migration, aboriginal policy, and environmental protection policy. The ADB divides projects into four categories, depending on the type, location, size, and impact it may have on the environment, setting different policies for each category. ${ }^{52} \mathrm{ADB}$ publicizes the social environmental impact and assessment documents of all projects or activities to which they provide funding. In addition, the ADB has set up a separate accountability mechanism, which includes two independent offices, the Special Projects

\footnotetext{
${ }^{49}$ IFC Grievance Mechanism, online: <https://www.ifc.org/wps/wcm/connect/4d94aa80488559ed849cd66a6515bb18/PartOne_GrievanceManagement.pd f?MOD=AJPERES $>$, accessed September 17, 2016

${ }^{50}$ Asian Development Bank, "Safeguards", online: <www.adb.org/site/safeguards/main>, accessed October 4, 2016.

${ }^{51}$ Asian Development Bank, "Safeguard Policy Statement”, online: <https://www.adb.org/documents/safeguardpolicy-statement>, accessed March 8, 2017.

52 Ibid.
} 
Promotion Office responsible for solving the problem, and the Compliance Audit Office responsible for compliance audits. 53

\section{c. The Asian Infrastructure Investment Bank}

The Asian Infrastructure Investment Bank (AIIB) is a multilateral investment and financing platform for OBOR to support infrastructure construction and development in Asia and the rest of the world. AIIB's commitment to sustainable development in the process of project screening, preparation and implementation, and effective management of potential environmental and social risks and shocks is critical to sustainable development of investment projects. AIIB has set "lean, clean and green" as governance principles to ensure its investment are economically, environmentally, and socially inclusive. In 2015, AIIB published the draft "Environment and Social Security Framework" and initiated the stakeholder consultation process. ${ }^{54}$ In addition, AIIB is committed to the 2017 Draft Energy Plan, which will only provide financial support for coalfired power plants in exceptional circumstances, and projects that do not meet the environmental and social security requirements will not be approved. ${ }^{55}$ In addition, AIIB is also actively seeking cooperation with existing international multilateral development banks to better practice and improve its existing environmental and social policies and establish effective accountability mechanisms. The Bank has signed a joint investment agreement with the World Bank and affirmed the adoption of the Bank's cooperation in the procurement, environmental and social security policy. Many environmental provisions of the AIIB Standards are on par with that of the IFC Standards. ${ }^{56}$ The AIIB's safeguards policy provides communication and participation channels for affected people and other stakeholders, and stakeholders can maintain their own benefits through the relevant channels during the design and implementation phases of the project. ${ }^{57}$

\footnotetext{
${ }^{53}$ More detailed information on the specific procedure can be found in the CAO Operational Guidelines, online: <www.cao-ombudsman.org>, accessed July 27, 2016.

${ }^{54}$ Asian Infrastructure Investment Bank, supra note 41.

55 Asian Infrastructure Investment Bank, "Energy Sector Strategy: Sustainable Energy for Asia" (June, 2017), online: < https://www.aiib.org/en/policies-strategies/strategies/sustainable-energyasia/.content/index/_download/aiib-energy-sector-Strategy-2017.pdf?>, accessed November 8. 2017.

${ }^{56}$ For instance, in its pollution prevention section, the AIIB's "Environmental and Social Framework" cites the World Bank Group's Environmental, Health and Safety Guidelines (EHSGs) and states that its projects will adhere to the EHSGs. Asian Infrastructure Investment Bank, supra note 41, at 32.

${ }^{57}$ Asian Infrastructure Investment Bank, supra note 41, at 21.
} 
Comparison of Environmental and Social Frameworks of Policy Bank and Financial Institutions

\begin{tabular}{|l|c|c|c|c|c|}
\hline & $\begin{array}{c}\text { China } \\
\text { Development } \\
\text { Bank }\end{array}$ & $\begin{array}{c}\text { China } \\
\text { Export- } \\
\text { Import Bank }\end{array}$ & $\begin{array}{c}\text { Asian } \\
\text { Infrastructure } \\
\text { Investment } \\
\text { Bank }\end{array}$ & $\begin{array}{c}\text { World } \\
\text { Bank }\end{array}$ & $\begin{array}{c}\text { Asian } \\
\text { Developme } \\
\text { nt Bank }\end{array}$ \\
\hline $\begin{array}{l}\text { Environmental and Social } \\
\text { Impact Assessment }\end{array}$ & Yes & Yes & Yes & Yes & Yes \\
\hline $\begin{array}{l}\text { Sectoral Industrial } \\
\text { Environmental and Social } \\
\text { Protection }\end{array}$ & Yes & No & Yes & Yes & Yes \\
\hline $\begin{array}{l}\text { Comply with Regulations } \\
\text { and Policies on } \\
\text { Environmental and Social } \\
\text { Impacts }\end{array}$ & Yes & Yes & Yes & Yes & Yes \\
\hline $\begin{array}{l}\text { Comply with International } \\
\text { Standards }\end{array}$ & Yes & Yes & Yes & Yes & Yes \\
\hline Information Disclosure & No & No & No & Yes & Yes \\
\hline Grievance Mechanism & No & No & No & Yes & Yes \\
\hline Third Party Monitoring & No & No & No & Yes & Yes \\
\hline $\begin{array}{l}\text { Assessment and Supervision } \\
\text { during Project Operation }\end{array}$ & Yes & Yes & Yes & Yes & Yes \\
\hline Aus & & & & & \\
\hline
\end{tabular}

Author's Compilation based on document: China's Development Financing under "The Belt and Road" Initiative ${ }^{58}$

\section{B. Lessons for Chinese Financial Institutions to Improve Environmental and Social Framework}

Through the brief overview and comparison of the environmental and social policies and systems of Chinese financial institutions and multinational financial institutions, Chinese financial institutions are still at the initial stage of integrating environmental and social considerations into their lending policies. Their environmental and social governance instruments do not contain comprehensive and transparent information disclosure mechanism, and do not ensure affected communities' access to their grievance mechanism. While some Chinese financial institutions confirm their support for sustainable development projects, they do not rule out the possibility of

58“China's Development Financing”, supra note 28. 
supporting fossil fuel projects in the future, unlike the World Bank Group and ADB. Given the above problems, this section proposes some suggestions that Chinese financial institutions should take to improve their lending and investment performances in the future. They include increasing awareness of green finance among Chinese financial institutions, ensuring transparency and disclosure on environmental and social risks, and enhancing supervision and compliance of Chinese financial institutions.

\section{a. Increase Awareness of Green Finance Among Chinese Financial Institutions}

Environmental risk analysis and green finance are still new concepts for Chinese financial institutions, and many Chinese financial institutions - especially private financial institutionsare not aware of the importance of environmental risk analysis. Chinese financial institutions should continually evolve their environmental and social risk management and policies practices to improve their analytical, assessment and management capabilities to identify and quantify the credit and market risks. Fuller understanding of environmental and social risks will help Chinese financial institutions better respond to investment risks, effectively internalize environmental externalities, achieve green operation of its financial business, and minimize the environmental and social impact of its investment and financing activities. An overall system of policy support could accelerate the development of green financial products and encourage investors to adjust their investment structure and promote green investment.

Particularly, due to the criticisms of overseas fossil fuel investment projects by Chinese companies, Chinese financial institutions should take full account of the impact of climate change in their investments, identify and manage the investment risks associated with climate policy and carbon risks to financial institutions, and contribute to clean and low-carbon energy transformation. From the comparison of environmental and social frameworks between Chinese financial institutions and international financial institutions, there is a gap between Chinese financial institutions' energy industry strategy and other multilateral financial institutions on fossil fuel investments. Many international financial institutions have withdrawn from coal and electricity projects, such as the World Bank and Asian Development Bank. China's renewable energy investment accounts 
for $28 \%$ per cent of total investment, compared with $88 \%$ for multilateral development banks. ${ }^{59}$ The carbon intensive Chinese infrastructure projects would greatly stimulate global greenhouse gas emissions, leading some developing countries to remain locked in fossil fuel energy systems for decades to come. Due to the high proportion of coal and hydropower investments, it will be a challenge for China's major policy banks and 13 new regional development funds to better address environmental risks and shift their investment targets to cleaner technologies. Although Chinese financial institutions made it clear that they will conditionally support efficient clean coal and oil and gas power generation projects, their attitude on coal and electricity is also of concern. Their overseas investment in coal projects is considered contrary to China's active green transformation. In light of China's massive progress in renewable energy investment, China can use this opportunity to shift more of its overseas financing toward clean energy sources. Sustainable financial products and services in renewable energy and clean technology will also present business opportunities for Chinese financial institutions. Providing sustainable financial products and services demonstrates a bank's commitment to sustainability, and can improve Chinese financial institutions' reputation as green and responsible institutions. ${ }^{60}$

\section{b. Ensure Transparency and Disclosure of Environmental and Social Risks}

Unlike international multilateral financial institutions, there is much room for Chinese financial institutions to improve the transparency of their lending policy, communication channels, and complaints mechanism. In general, Chinese financial institutions have not provided, to their different stakeholders, effective communication and sufficient information on project selection and assessment criteria, on the negative impacts of the projects on affected regions and groups, and the resulting dispute resolutions. Hence, China has issued the Measures for Information Disclosure by Commercial Banks ${ }^{61}$, requiring banks to disclose information related to risks. China's Securities Regulatory Commission also requires listed banks to disclose environmental information. However, China has not issued any mandatory regulations and standards on environmental information disclosure. Further measures that could be taken include establishing

\footnotetext{
${ }^{59}$ Beth Walker, "China Stokes Global Coal Growth" (September, 2016), Chinadialogue, online: <https://www.chinadialogue.org.cn/article/show/single/en/9264-China-stokes-global-coal-growth>, accessed on October 9, 2017.

${ }^{60}$ International Energy Agency, "World Energy Outlook" (2017), online: <www.iea.org/weo/>, accessed December 19, 2017.

${ }^{61}$ China Banking Regulatory Commission, "Measures for Information Disclosure by Commercial Banks" (July, 2007), online: 〈http://www.gov.cn/ziliao/flfg/2007-07/27/content_698898.htm〉, accessed April 24, 2016.
} 
stable coordination mechanisms between environmental, financial, and industrial regulators to ensure the uniformity and stability of green finance policies and enable communication and information sharing on technical information. Another measure is the establishment of cooperation mechanisms with third-party institutions to take advantage of private standards and intermediaries as a complement to legal and policy approaches.

Specifically, Chinese financial institutions should establish effective coordination and information sharing to enhance communication between financial regulatory authorities and government administrative departments. Financial institutions could participate in and actively organize investment companies to communicate with local governments and local communities in the host countries in order to identify and resolve problems in a timely manner. In the process of overseas project loans, the control of environmental and social impact needs to be strengthened, including the approval stage, the project implementation process and the post-operation monitoring of financed projects. Financial institutions should fully disclose environmental and social information through corporate social responsibility reports and strengthen public participation to ensure accountability to affected communities, especially in countries where regulatory agencies are not well developed. It is essential that financed projects' documents be made available to affected communities and people before project approval. The information that should be documented and disclosed include the project name, location and sector, environmental impact assessments, social impact assessments, indigenous peoples plans, and resettlement action plans. In addition, financial institutions should openly collaborate with third parties to disclose environmental information in local projects and enhance communication with stakeholders. It will be easier for Chinese financial institutions to form a sound consultation mechanism with local communities and build trust for investment projects to proceed smoothly by utilizing the diversity of experience, knowledge, and perspectives of local informants, think tanks, and NGOs.

\section{c. Enhance Supervision and Compliance of Chinese Financial Institutions}

\section{Enhance Internal Monitoring Mechanism}

There is a need to enhance Chinese financial institutions' institutional capacity in order to ensure the effectiveness of internal monitoring and categorizing. In particular, institutions should create specialized teams for assessing environmental and social risks in their credit and lending businesses and establish strict environmental and social risk management auditing and review 
systems for financed projects to enhance their internal monitoring mechanisms. Financial institutions should commit to carrying out due diligence, monitoring, and supervision operations in high risk sub-projects and categorize potential client projects based on type of investment industry. Transactions that pose significant reputational risk should be further reported to the institution's CEO and President for review.

In addition, green finance requires specialist knowledge about technologies and environmental risks, with the support of professional technical evaluation to appraise impacts, costs, and risks, and guide the existing professional service institutions. ${ }^{62}$ Chinese financial institutions should set up specialized environmental and social risk teams with experience and expertise to conduct environmental and social impact assessment. This is particularly important for reviewing high risk transactions and investments. Financial institutions need to periodically undertake internal verification and checks to evaluate the consistency of environmental and social risk policy and risk analysis. These audit teams should regularly interact with financial institutions in order to support the development and improvement of procedures and internal controls for environmental and social analysis. ${ }^{63}$ Post-lending monitoring process for financial institutions should include regularly checking the state environmental protection authorities' list of clients punished for violating regulations, improving systems for early warning about environmental risks, and carrying out on-the-spot inspections and responding promptly to emergencies. The department in charge of credit risk management or sustainable finance should be based either at the headquarters or branches of financial institutions. Each branch's sustainable finance department can formulate evaluations based on the information it receives from the bank's operations department, and the evaluations will then be delivered to headquarters for checking. Engagement between front office and environmental and social risk systems is therefore critical to the environmental and social risk management process.

In addition, Chinese financial institutions also need to obtain independent third-party assurance and introduce external assurance for their environmental and social risk management systems. For high and substantial risk sub-projects, it should be a compulsory requirement for Chinese financial

\footnotetext{
${ }^{62}$ Wang Qingrong, Lilian Wang, Sun Yiting \& Guo Lina, "The Sustainable Performance of Chinese Banking and International Financial Institutions Comparative Study" (WWF China: 2013), online: <http://www.wwfchina.org/content/press/publication/2015/greenfinanceen.pdf>, accessed October 25, 2016.

63 Ibid.
} 
institutions to hire professional third party auditing organization to carry out environmental and social risk assessment. They should also invite independent third party rating agencies to review their annual corporate social responsibility reports and assess environmental and social risks and incorporate them into ratings. This will help financial institutions more readily identify and manage environmental and social risks in their portfolios.

\section{Set Up Grievance Mechanisms}

In addition to the development and improvement of safeguard policies, international financial institutions have set up independent complaint mechanisms to deal with project complaints and protect local communities and residents in investment activity locations. In order to monitor whether enterprises follow the protection policy, Chinese financial institutions should also set up independent complaint and accountability mechanisms to deal with project-related complaints and ensure the implementation of environmental and social safeguard policies. Grievance mechanisms aim at promoting dispute-resolution through dialogue, and by identifying facts or providing advice or statements. They are a formal and legal mechanism for the service of individuals, employees, or communities that are adversely affected by certain commercial issues. ${ }^{64}$ Any person, group, or community affected, or likely to be affected, is eligible to file complaints that may relate to any aspect of the planning, implementation or impact of a Chinese-financed project. The grievance mechanism is also an independent oversight authority that reports directly to the president of the financial institutions to ascertain the application of the environmental and social protection standards. Complaints filed through the grievance mechanism should be continuously monitored and disclosed after a project has been approved for implementation, and to properly resolve disputes or conduct compliance survey. ${ }^{65}$ Besides seeking to resolve issues for individuals who are directly affected or likely to be directly affected by financed projects, such grievance mechanisms can also provide financial institutions with policy advice on environmental and social performance

\footnotetext{
${ }^{64}$ The Asian Development Bank and the World Bank's International Finance Corporation have set up a Compliance Audit Office and the position of Compliance Advisor/Ombudsman, responsible for compliance audits and dealing specifically with complaints with three functions of dispute resolution, compliance investigation and consultancy. See European Investment Bank, "Database of Complaints Mechanism Cases", online: <www.eib.org/about/accountability/complaints/cases/index.htm>, accessed August 9, 2017.

${ }^{65}$ Antoni Pigrau Solé, et al, "Human Rights in European Business: A Practical Handbook for Civil Society Organizations and Human Rights Defenders" (September, 2016), online: <http://humanrightsinbusiness.eu/wpcontent/uploads/2016/09/HUMAN_RIGHTS_IN_EUROPEAN_BUSINESS_EN.pdf>, accessed November 25, 2016.
} 
and to assist in conducting environmental and social audits and reviews. ${ }^{66}$ The ombudsman's team conducts field visits to the site of contested projects and interviews with all parties involved: staff of the private company, local authorities, affected communities representatives, and other relevant local organizations and staff. Complaints, reports of field missions, and recommendations are all published on the compliance ombudsman's website, together with updates on ongoing investigations. After considering complaints, the Compliance Advisor/Ombudsman formulates recommendations not only to the financial institution itself, but also directly to the private company involved. Financial institutions are required to appoint independent personnel to oversee the projects and report on social and environmental matters, and investment companies are requested to report to Chinese financial institutions on a quarterly and annual basis on social and environmental issues. If the impacts of the projects violate the safeguards policy and the relevant criteria after investigation and assessment, financial institutions can therefore revoke the project funds.

\section{Enhance the Responsibility of Director and Senior Manager}

Commitment to sustainability from the board of directors of Chinese financial institutions is vital to the successful implementation of environmental and social risk management. Encouraging and supporting directors to have proper regard for these issues is a key step towards ensuring that business is geared towards building an economy that recognizes the interrelated economic, social, human, and environmental drivers of prosperity and wellbeing. It communicates that directors who fail to consider the impact of foreseeable climate change risks on their business properly could be held personally liable for breaching the duty of due care and diligence they owe to their companies. Financial institutions' directors should take climate change and related environmental and social sustainability risks into account, especially where those risks are (potentially) material to the interests of institutions. This reaffirms that directors need to take a wide range of considerations into account when deciding what is in the best interests of a company, rather than focusing solely on immediate shareholder value maximization. Board-level accountability demonstrates to both internal and external stakeholders that financial institutions take sustainability seriously, and

\footnotetext{
${ }^{66}$ Ibid.
} 
ensures that sufficient attention and resource is directed at managing environmental and social issues.

First, Chinese financial institutions should ensure that the board of directors or senior management approves a sustainability policy and subjects that policy to frequent review and updates. ${ }^{67}$ The Board is responsible for the financial institution's development strategy and risk management policies, including policies related to green credit and sustainable development. The board and credit policy committee of financial institutions should continuously monitor and evaluate their sustainability policy, and review and update their environmental and social risk management strategies and development direction annually. Specific responses should include greater investment in risk analysis and integrated reporting; more focus on technical support and consolidating measurement of sustainability-related risks; and adoption of transparency and disclosure of environmental and social risks. Further work for Chinese financial institutions should focus on increasing awareness in the director community of the importance of properly considering climate change and other sustainability risks. This would include encouraging regulators to raise expectations about proper management, supervision, and disclosure of environmental, social, and governance risks, and promoting constructive engagement by business leaders on long-term policy challenges to support policies that can avert the need to adjust to the inevitable trends and challenges of environmental and social risks.

To ensure that directors and senior managers will take responsibility in integrating environmental and social policies into their lending policies, the sustainability criteria should be considered as an important evaluation factor when determining senior management ratings and remuneration. Only those with full-time roles in sustainability are remunerated based on the bank's sustainability performance. To be more specific, the directors and senior management of Chinese financial institutions should be evaluated in part by their performance in carrying out sustainable development goals. A relevant performance indicator on that regard could be "social contribution per share." 68 In addition to stressing the value of current performance, Chinese financial institutions can retain a certain percentage of senior management's performance-based income as

\footnotetext{
${ }^{67}$ Center for Policy Development, "New Legal Opinion and Business Roundtable on Climate Risk and Directors' Duties" (October 2016), online: <cpd.org.au/2016/10/directorsduties/>, accessed March 8, 2017.

${ }^{68}$ Wang et al., supra note 62 , at 9.
} 
a risk fund realized in a few years based on evaluation results. ${ }^{69}$ These measures have been designed to prevent management from focusing only on producing short-term results, and to ensure financial institution's long-term sustainable development overseas.

${ }^{69}$ Ibid. 